\title{
PENGARUH KECEMASAN STATISTIKA TERHADAP KEMAMPUAN PENALARAN STATISTIK DALAM PEMBELAJARAN KOLABORATIF BERBANTUAN EDMODO
}

\author{
(THE INFLUENCE OF STATISTICS ANXIETY ON REASONING \\ STATISTICAL ABILITY IN EDMODO-ASSISTED COLLABORATIVE \\ LEARNING)
}

\author{
Ahmad Dzulfikar \\ Institut Agama Islam Negeri Pekalongan, ahmad.dzulfikar@iainpekalongan.ac.id
}

\begin{abstract}
Abstrak
Temuan-temuan penelitian terdahulu menunjukkan hasil tidak konsisten tentang pengaruh kecemasan statistika terhadap performa akademik seseorang dalam statistika. Oleh karena itu, dalam penelitian ini dikaji ada tidaknya pengaruh kecemasan statistika terhadap kemampuan penalaran statistik mahasiswa dalam pembelajaran kolaboratif berbantuan Edmodo. Penelitian ini adalah penelitian korelasional dengan pendekatan kuantitatif. 40 mahasiswa peserta mata kuliah Statistika di sebuah perguruan tinggi di Jawa Tengah menjadi sampel dalam penelitian ini. Sampel tersebut dipilih secara cluster random sampling. Instrumen dalam penelitian ini adalah skala kecemasan statistika dan tes kemampuan penalaran statistik yang telah teruji valid dan reliabel. Temuan penelitian ini adalah ada pengaruh negatif kecemasan statistika terhadap kemampuan penalaran statistik mahasiswa. Lebih lanjut, hasil penelitian ini menemukan bahwa kecemasan statistika memberikan sumbangsih sebesar 28,6\% terhadap kemampuan penalaran statistik mahasiswa. Dengan pemahaman aspek kognitif dan afektif dalam pembelajaran statistika diharapkan dapat mengoptimalkan prestasi belajar statistika mahasiswa.
\end{abstract}

Kata kunci: kecemasan statistika, kemampuan penalaran statistik, pembelajaran kolaboratif, edmodo

\begin{abstract}
The results of previous studies showed inconsistent results about the influence of statistics anxiety on academic performance in statistics. Therefore, this study examines the influence of statistics anxiety on students' statistical reasoning ability in Edmodo-assisted collaborative learning. This research is a correlational research with a quantitative approach. 40 students participating in Statistics course at a university in Central Java were the samples in this study which were selected by cluster random sampling. The instruments in this study are a statistics anxiety scale and statistical reasoning ability tests that have been tested to be valid and reliable. The finding of this study is there is a negative influence of statistics anxiety on students' statistical reasoning ability. Furthermore, the results of this study found that statistics anxiety contributed $28.6 \%$ to the students' statistical reasoning ability. By understanding the cognitive and affective aspects in statistics learning, it is possible to optimize students' statistics learning performance.
\end{abstract}

Keywords: statistics anxiety, statistical reasoning ability, collaborative 
learning, edmodo

\section{PENDAHULUAN}

Terjadinya pandemi Covid-19 memaksa terjadinya revolusi dalam bidang pendidikan. Menurut Goldschmidt (2020), pandemi Covid-19 telah menyebabkan terjadinya tsunami pembelajaran daring. Lebih lanjut, Bao (2020) menyatakan bahwa pandemi Covid-19 telah memaksa terjadinya migrasi massal dari pembelajaran berbasis tatap muka ke pembelajaran daring.

Migrasi ini juga terjadi dalam pelaksanaan pembelajaran statistika. Platform yang dapat menjadi media pembelajaran daring salah satunya adalah Edmodo. Meskipun pelaksanaan pembelajaran dilaksanakan secara daring, tetapi capaian pembelajaran statistika tetap harus dioptimalkan. Untuk dapat berhasil dalam mengikuti pembelajaran statistika mahasiswa perlu didukung dengan kemampuan penalaran yang baik. Dalam statistika, kemampuan ini disebut sebagai kemampuan penalaran statistik.

Kemampuan penalaran statistik ini dapat diindikasikan sebagai kemampuan seseorang dalam memahami dan memberi pemaknaan pada data, melakukan analisis statistik, dan menginterpretasikan hasil analisis yang diperoleh terhadap masalah yang diberikan (Garfield \& Gal, 1999; Maryati \& Priatna, 2017). Hasilhasil penelitian terdahulu menemukan bahwa kemampuan penalaran statistika mahasiswa rendah (Dzulfikar, 2020; Ulusoy \& Altay, 2017; Yusuf, Suyitno, Sukestiyarno, \& Isnarto, 2019).

Terkait pengembangan kemampuan penalaran statistik, Sariningsih \& Herdiman (2017) memberikan rekomendasi bahwa mahasiswa perlu disajikan konten esensial yang dibutuhkan, difasilitasi bahan belajar dan bantuan dari dosen sesuai kebutuhan mereka. Berdasarkan rekomendasi tersebut, peneliti mengimplementasikan pembelajaran kolaboratif berbantuan Edmodo sebagai model pembelajaran statistika. Model pembelajaran ini akan memfasilitasi mahasiswa untuk saling tergantung secara positif, bertanggung jawab, dan berinteraksi antar anggota dalam kelompok serta dengan dosen. Selain itu, mahasiswa akan bekerja secara aktif dan berkelompok untuk menyelesaikan permasalahan yang diberikan guna memperoleh pemecahan masalah serta mengatasi kesulitan yang dihadapi.

Edmodo adalah program pembelajaran yang dirancang berbasis jejaring sosial yang dapat membantu membangun kelas virtual. Septian \& Aulia (2021) menyebutkan bahwa Edmodo membantu dosen membangun kelas virtual seperti di kelas tatap muka, seperti diskusi kelompok di kelas virtual, dimana setiap mahasiswa dapat dengan bebas berkomunikasi dan berinteraksi dengan dosen dan mahasiswa lain dan menanggapi materi yang disampaikan, serta mendorong lingkungan virtual kolaboratif. Dengan berbantuan Edmodo mahasiswa akan lebih bersemangat karena mereka sudah terbiasa menggunakan media sosial. Platform Edmodo yang mirip dengan media sosial ini bisa digunakan sebagai media untuk belajar.

Statistika sebagai sebuah mata kuliah seringkali menjadi tantangan dan tidak jarang menimbulkan kecemasan pada diri seseorang (Sandoz, Butcher, \& Protti, 2017). Penelitian sebelumnya menunjukkan banyak mahasiswa yang memiliki kecemasan ketika berhadapan dengan statistika (Dzulfikar, 2021; Steinberger, 2020; Tutkun, 2019; Zhang, Kessler, \& Braasch, 2021). 
Kecemasan statistika dapat diartikan sebagai keadaan emosi negatif yang ditunjukkan dengan sebuah kecemasan pada diri seseorang ketika berhadapan dengan statistika di berbagai jenjang dan menjadi penghambat perfoma belajarnya (Onwuegbuzie \& Daley, 1999; Steinberger, 2020; Tutkun, 2019; Zhang et al., 2021). Lavasani, Weisani, \& Shariati (2014) dan Zhang et al. (2021) menyatakan bahwa kecemasan statistika berhubungan negatif terhadap motivasi akademik dan menjadi penghambat perfoma belajar statistika seseorang. Oleh karena itu, kecemasan statistika dapat menghambat tercapainya capaian pembelajaran statistika.

Berdasarkan uraian tersebut, kecemasan statistika dapat memberikan pengaruh negatif terhadap prestasi statistika seseorang. Akan tetapi, hasil-hasil penelitian terdahulu tidak menunjukkan temuan yang konsisten terkait dampak kecemasan statistika ini. Yusuf et al. (2019) dalam penelitiannya menemukan tidak ada pengaruh kecemasan statistika terhadap kemampuan statistika pada mahasiswa calon guru. Penelitian lain menemukan bahwa kecemasan statistika ini memiliki dampak negatif terhadap kemampuan atau performa statistika seseorang (Auliya \& Munasiah, 2017; Kawsar, Zahan, \& Islam, 2019; Siew, McCartney, \& Vitevitch, 2019; Tutkun, 2019). Sementara itu, temuan Macher et al. (2013) menunjukkan bahwa kecemasan statistika berpengaruh negatif secara tidak langsung terhadap kemampuan statistika, tetapi menunjukkan adanya pengaruh langsung dan positif terhadap kemampuan statistika seseorang.

Adanya temuan-temuan penelitian sebelumnya yang tidak konsisten tersebut mendorong pentingnya penelitian lanjutan untuk menguji adakah pengaruh kecemasan statistika terhadap kemampuan penalaran statistik. Dengan pemahaman aspek-aspek dalam pembelajaran statistika, baik kognitif maupun afektif diharapkan dapat mengoptimalkan kemampuan dan prestasi belajar statistika mahasiswa. Oleh karena itu, tujuan penelitian ini adalah untuk mengkaji pengaruh kecemasan statistika terhadap kemampuan penalaran statistik mahasiswa dalam pembelajaran kolaboratif berbantuan Edmodo.

\section{KAJIAN TEORI}

\section{A. Kecemasan Statistika}

Kecemasan statistika dapat diartikan sebagai keadaan emosi negatif yang ditunjukkan dengan sebuah kecemasan pada diri seseorang ketika berhadapan dengan statistika di berbagai jenjang dan menjadi penghambat perfoma belajarnya (Onwuegbuzie \& Daley, 1999; Steinberger, 2020; Tutkun, 2019; Zhang et al., 2021). Sementara itu, Steinberger (2020) dan Cui, Zhang, Guan, Zhao, \& Si (2019) menjelaskan keadaan emosi negatif seseorang yang ditunjukkan dengan sebuah kecemasan pada diri seseorang ketika berhadapan dengan statistika di berbagai jenjang yang terkait, tetapi berbeda dengan kecemasan matematika. Oleh karena itu, kecemasan statistika berbeda dengan kecemasan matematika atau kecemasan lainnya. Karena pada dasarnya, kecemasan statistika tergolong sebagai state anxiety, yaitu kecemasan yang menetap ketika suatu kondisi itu ada, dalam hal ini adalah statistika.

Untuk mendefinisikan kecemasan statistika seseorang dapat diidentifikasi dari dimensi-dimensi yang ada pada kecemasan statistika. Dimensi tersebut adalah kecemasan menghadapi kelas dan tes statistika, konsep diri terhadap operasi 
matematika, kecemasan meminta bantuan, dan kecemasan terhadap pengajar statistika (Nesbit \& Bourne, 2018; Sandoz \& Hebert, 2017; Steinberger, 2020).

\section{B. Kemampuan Penalaran Statistik}

Kemampuan dalam statistika yang perlu dimiliki mahasiswa diantaranya adalah kemampuan penalaran statistik. Penalaran statistik melibatkan kegiatan komprehensif, yang meliputi pemahaman dan pemaknaan data statistik, melakukan analisis statistik, serta melakukan interpretasi terhadap hasil dan proses analisis statistik tersebut (Garfield \& Ben-zvi, 2009; Yusuf, 2017).

Kemampuan penalaran statistik dapat didefinisikan sebagai kemampuan seseorang dalam memahami dan memberi pemaknaan pada data, melakukan analisis statistik, dan menginterpretasikan hasil analisis yang diperoleh terhadap masalah yang diberikan (Garfield \& Gal, 1999; Maryati \& Priatna, 2017). Dalam mengidentifikasi kemampuan penalaran statistik, terdapat beberapa indikator. Indikator tersebut adalah: (1) kemampuan memahami dan memberi makna pada data, (2) kemampuan menyusun strategi dan proses atau analisis statistik, (3) kemampuan membuat interpretasi terhadap hasil analisis statistika yang telah diperoleh, dan (4) kemampuan melakukan evaluasi terhadap proses dan hasil analisis statistika yang telah dilakukan (Chan \& Ismail, 2014; Maryati \& Priatna, 2017; Yusuf, 2017).

\section{METODE}

Penelitian ini berjenis penelitian korelasional dengan pendekatan kuantitatif. Seluruh mahasiswa yang mengambil mata kuliah statistika di sebuah perguruan tinggi di Jawa Tengah pada 2020 menjadi populasi dalam penelitian ini. Sampel dalam penelitian ini adalah 40 mahasiswa yang memperoleh pembelajaran statistika dengan model pembelajaran kolaboratif berbantuan Edmodo yang dipilih secara cluster random sampling.

Instrumen yang digunakan dalam penelitian ini adalah skala kecemasan statistika dan tes kemampuan penalaran statistik. Untuk mengidentifikasi kemampuan penalaran statistik mahasiswa digunakan adaptasi dari indikatorindikator yang dikembangkan oleh Chan \& Ismail (2014), Maryati \& Priatna (2017), dan Yusuf (2017). Sementara, untuk mengidentifikasi kecemasan statistika mahasiswa instrumen dikembangkan berdasarkan indikator-indikator yang dikembangkan oleh Nesbit \& Bourne (2018), Sandoz \& Hebert (2017), dan Steinberger (2020). Kedua instrumen tersebut digunakan setelah sebelumnya dinyatakan valid dan reliabel.

\section{HASIL DAN PEMBAHASAN}

Tujuan penelitian ini adalah untuk mengkaji pengaruh kecemasan statistika terhadap kemampuan penalaran statistik. Tabel 1 berikut menyajikan skor kecemasan statistika dan kemampuan penalaran statistik 40 mahasiswa yang memperoleh pembelajaran kolaboratif berbantuan Edmodo. 
Tabel 1. Statistik Deskriptif Kecemasan Statistika dan Kemampuan Penalaran Statistik Mahasiwa

\begin{tabular}{lcccc}
\hline \multicolumn{1}{c}{ Variabel } & $\begin{array}{c}\text { Rata- } \\
\text { rata }\end{array}$ & $\begin{array}{c}\text { Simpangan } \\
\text { Baku }\end{array}$ & Skor Ideal & Level \\
\hline Kecemasan Statistika & 45.50 & 7.13 & 76.00 & Sedang \\
\hline Kemampuan Penalaran Statistik & 24.20 & 4.78 & 40.00 & Sedang \\
\hline
\end{tabular}

Mengacu data pada tabel 1, dapat dilihat bahwa rata-rata skor kecemasan statistika mahasiswa yang memperoleh perkuliahan kolaboratif berbantuan Edmodo adalah 45,5. Kecemasan statistika ini tergolong pada tingkat sedang. Hasil ini memperkuat temuan Yusuf et al. (2019) bahwa secara umum kecemasan statistika mahasiswa berada pada level sedang. Berdasarkan tabel 1 juga diperoleh informasi bahwa rata-rata skor kemampuan penalaran statistik mahasiswa yang memperoleh perkuliahan kolaboratif berbantuan Edmodo adalah 24,2. Skor 24,2 atau 60,5\% dari skor ideal tergolong pada level sedang (Olani, Hoekstra, Harskamp, \& Van der Werf, 2017).

Untuk menguji ada tidaknya pengaruh kecemasan statistika terhadap kemampuan penalaran statistik mahasiswa dalam pembelajaran kolaboratif berbantuan Edmodo, analisis regresi linear sederhana digunakan dalam penelitian ini. Sebuah model regresi yang baik, residual datanya harus berdistribusi normal. Berikut ini adalah hasil uji normalitas residu dengan grafik.

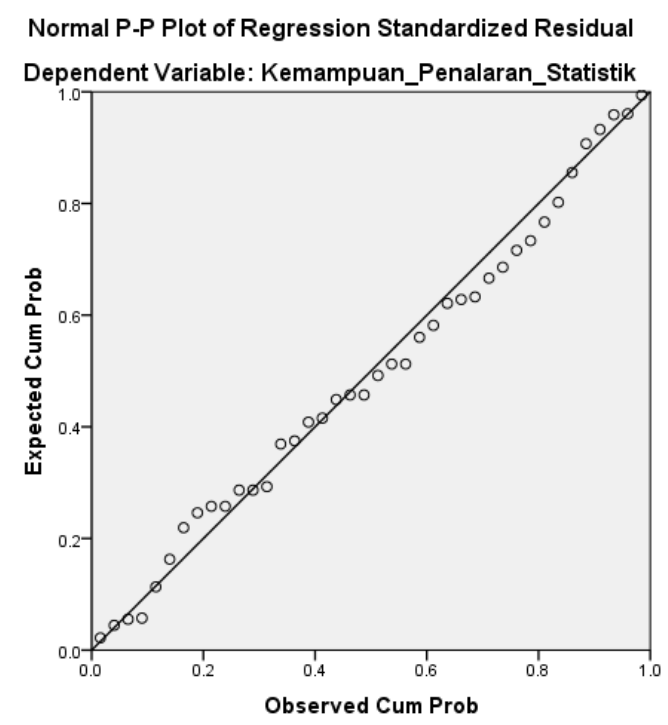

Gambar 1. Hasil Uji Normalitas Residual Data

Berdasarkan Gambar 1 tampak bahwa titik-titik menyebar mendekati garis lurus. Oleh karena itu, dapat diinterpretasikan bahwa residual data berdistribusi normal.

Asumsi klasik lain yang harus dipenuhi agar menjadi model regresi linear yang baik adalah terbebas dari heteroskedastisitas. Salah satu metode yang dapat digunakan adalah dengan scatterplot. Berikut disajikan scatterplot hasil uji heteroskedastisitas. 


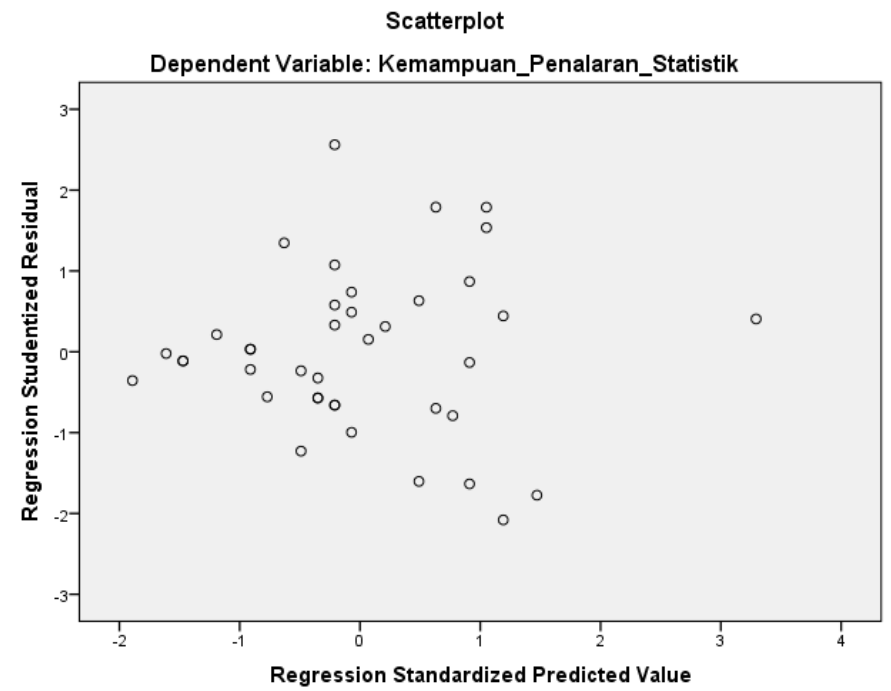

Gambar 2. Hasil Uji Heteroskedastisitas

Dengan memperhatikan persebaran titik-titik pada Gambar 2 diketahui bahwa titik-titik tersebut menyebar pada sumbu Y positif dan negatif. Selain itu, pada gambar tersebut tampak bahwa persebaran titik-titik tidak menunjukkan adanya pola tertentu. Berdasarkan hasil ini dapat diinterpretasikan bahwa tidak terjadi heteroskedastisitas.

Terpenuhinya asumsi normal dan homoskedastisitas berimplikasi pada dapat dilakukannya analisis regresi linear sederhana. Hasil analisis regresi linear sederhana disajikan pada tabel-tabel berikut.

Tabel 2. Hasil Uji Koefisien Determinasi

Model Summary ${ }^{b}$

\begin{tabular}{clrrr}
\hline Model & R & R Square & Adjusted R Square & Std. Error of the Estimate \\
\hline 1 & $.535^{\mathrm{a}}$ & .286 & .267 & 4.09061
\end{tabular}

a. Predictors: (Constant), Kecemasan_Statistika

b. Dependent Variable: Kemampuan_Penalaran_Statistik

Tabel 3. Hasil Uji Kecocokan Model

\begin{tabular}{|c|c|c|c|c|c|c|}
\hline \multicolumn{7}{|c|}{ ANOVA $^{a}$} \\
\hline & Model & $\begin{array}{c}\text { Sum of } \\
\text { Squares }\end{array}$ & df & $\begin{array}{l}\text { Mean } \\
\text { Square }\end{array}$ & $\mathrm{F}$ & Sig. \\
\hline \multirow{3}{*}{1} & Regression & 254.542 & 1 & 254.542 & 15.212 & $.000^{\mathrm{b}}$ \\
\hline & Residual & 635.858 & 38 & 16.733 & & \\
\hline & Total & 890.400 & 39 & & & \\
\hline
\end{tabular}

a. Dependent Variable: Kemampuan_Penalaran_Statistik

b. Predictors: (Constant), Kecemasan_Statistika 
Tabel 4. Hasil Uji Pengaruh Kecemasan Statistika terhadap Kemampuan Penalaran Statistik Mahasiswa dalam Pembelajaran Kolaboratif Berbantuan Edmodo

\begin{tabular}{|c|c|c|c|c|c|c|}
\hline \multicolumn{7}{|c|}{ Coefficients $^{\mathrm{a}}$} \\
\hline & \multirow[t]{2}{*}{ Model } & \multicolumn{2}{|c|}{$\begin{array}{l}\text { Unstandardized } \\
\text { Coefficients }\end{array}$} & \multirow{2}{*}{$\begin{array}{c}\begin{array}{c}\text { Standardized } \\
\text { Coefficients }\end{array} \\
\text { Beta }\end{array}$} & \multirow[t]{2}{*}{$\mathrm{t}$} & \multirow[t]{2}{*}{ Sig. } \\
\hline & & B & Std. Error & & & \\
\hline \multirow{2}{*}{1} & (Constant) & 40.489 & 4.226 & & 9.580 & .000 \\
\hline & Kecemasan Statistika & -.358 & .092 & -.535 & -3.900 & .000 \\
\hline
\end{tabular}

a. Dependent Variable: Kemampuan_Penalaran_Statistik

Hasil penelitian tersebut menunjukkan bahwa kecemasan statistika berpengaruh negatif terhadap kemampuan penalaran statistik mahasiswa dalam pembelajaran kolaboratif berbantuan Edmodo. Hal ini ditunjukkan dengan nilai signifikansi sebesar 0,000 yang kurang dari $\alpha=0,05$ dan nilai $t$ yang bernilai negatif. Temuan ini berseberangan dengan temuan Yusuf et al. (2019) yang menemukan bahwa tidak ada pengaruh kecemasan statistika terhadap kemampuan penalaran statistik mahasiswa.

Ketika mahasiswa belajar statistika, mereka cenderung belajar berdasarkan buku teks yang ada, yang terkadang substansi dan pertanyaan yang diberikan tidak terlalu real bagi mereka (Shiu, 2013). Oleh karena itu, terkadang mahasiswa kurang memahami manfaat nyata dari belajar statistika baik untuk perkembangan akademik maupun kehidupan dan kariernya. Hal ini yang kemudian memunculkan kecemasan statistika pada diri seseorang.

Kecemasan statistika dapat menjadi hambatan bagi perkuliahan statistika karena berkorelasi negatif dengan motivasi akademik seseorang (Lavasani et al., 2014; Zhang et al., 2021). Hal ini dikarenakan mahasiswa dengan kecemasan statistika cenderung menghindari statistika, kecuali mereka merasa terdesak membutuhkannya (Sandoz et al., 2017). Oleh karena itu, kecemasan statistika juga terkait dengan motivasi belajar yang muaranya adalah prestasi belajar mahasiswa dalam statistika.

Kecemasan statistika yang tinggi pada diri seseorang ditunjukkan dengan adanya perasaan tidak nyaman dan sikap negatif ketika mereka mengikuti kelas statitsika, menyelesaikan masalah statistika, mengerjakan ujian, dan menyampaikan pendapat di kelas statistika (Malik, 2015; Siew et al., 2019). Oleh karena itu, kecemasan statistika terkait dengan prestasi statistika mahasiswa yang dalam hal ini adalah kemampuan penalaran statistik.

Berdasarkan data pada Tabel 4 diketahui bahwa semakin besar tingkat kecemasan statistika mahasiswa berdampak pada semakin rendah pula kemampuan penalaran statistiknya. Oleh karena itu, untuk meningkatkan kemampuan penalaran statistik mahasiswa, maka dalam pembelajaran kecemasan statistika mereka perlu untuk direduksi.

Hasil uji koefisien determinasi pada Tabel 2 diperoleh nilai $R^{2}=0.286$. Hasil tersebut dapat diinterpretasikan bahwa kecemasan statistika memberikan pengaruh kepada kemampuan penalaran statistik mahasiswa sebesar 28,6 \%. Sementara itu, 71,4 \% lainnya dipengaruhi oleh variabel lain, seperti pembelajaran berbantuan Edmodo dan variabel lain yang tidak diteliti dalam penelitian ini. 


\section{SIMPULAN DAN SARAN}

Tujuan penelitian ini adalah untuk menguji ada tidaknya pengaruh kecemasan statistika terhadap kemampuan penalaran statistik mahasiswa dalam pembelajaran kolaboratif berbantuan Edmodo. Penelitian ini menemukan bahwa kecemasan statistika memberikan pengaruh negatif terhadap kemampuan penalaran statistik mahasiswa dalam pembelajaran kolaboratif berbantuan Edmodo dengan sumbangsih sebesar 28,6\%. Oleh karena itu, untuk meningkatkan kemampuan penalaran statistik mahasiswa, pengajar perlu untuk memberikan atensi dan berupaya untuk mereduksi kecemasan statistika mahasiswa dalam pembelajaran. Dalam penelitian ini masih terbatas pada sebuah domain afektif, penelitian selanjutnya dapat mengkaji pengaruh domain afektif atau kognitif lainnya yang diduga juga dapat mempengaruhi kemampuan penalaran statistik mahasiswa dengan lingkup yang lebih luas. Dengan pemahaman aspek kognitif dan afektif seperti kemampuan penalaran statistik dan kecemasan dalam pembelajaran statistika diharapkan dapat mengoptimalkan prestasi belajar statistika mahasiswa.

\section{DAFTAR RUJUKAN}

Auliya, R. N., \& Munasiah. (2017). Pengaruh kecemasan statistika terhadap literasi statistik. Jurnal Penelitian Pendidikan Matematika, 2(1), 166-175.

Bao, W. (2020). COVID -19 and online teaching in higher education: A case study of Peking University . Human Behavior and Emerging Technologies, 2(2), 113-115. https://doi.org/10.1002/hbe2.191

Chan, S. W., \& Ismail, Z. (2014). Developing statistical reasoning assessment instrument for high school students in descriptive statistics. Procedia - Social and Behavioral Sciences, 116, 4338-4343. https://doi.org/10.1016/j.sbspro.2014.01.943

Cui, S., Zhang, J., Guan, D., Zhao, X., \& Si, J. (2019). Antecedents of statistics anxiety: An integrated account. Personality and Individual Differences, 144(February), 79-87. https://doi.org/10.1016/j.paid.2019.02.036

Dzulfikar, A. (2020). Meningkatkan Kemampuan Penalaran Statistik dan Mereduksi Kecemasan Statistika Mahasiswa Melalui Perkuliahan Kolaboratif Berbantuan Edmodo. Pekalongan.

Dzulfikar, A. (2021). Profiling the college students' anxiety in statistics lectures. Journal of Medives: Journal of Mathematics Education IKIP Veteran Semarang, 5(2), 261. https://doi.org/10.31331/medivesveteran.v5i2.1668

Garfield, J., \& Ben-Zvi, D. (2009). Helping Students Develop Statistical Reasoning : Teaching Statistics.

Garfield, J., \& Gal, I. (1999). Teaching and assessing statistical reasoning: national council teachers of mathematics 1999 year. In L. Stiff (Ed.), Developing Mathematical Reasoning in Grades K-12: National Council Teachers of Mathematics 1999 Year (pp. 207-219).

Goldschmidt, K. (2020). The covid-19 pandemic: technology use to support the wellbeing of children. Journal of Pediatric Nursing, 53(xxxx), 88-90. https://doi.org/10.1016/j.pedn.2020.04.013

Kawsar, L. A., Zahan, F. N., \& Islam, M. A. (2019). Relationship among statistics anxiety, depression, and academic performance. In M. R. Karim \& M. A. Khalek (Eds.), Proceedings 7th International Conference on Data Science and 
SDGs: Challenges, Opportunities, and Realities (pp. 149-157). Dhaka, Bangladesh: University of Rajshahi.

Lavasani, M. G., Weisani, M., \& Shariati, F. (2014). The role of achievement goals, academic motivation in statistics anxiety: testing a causal model. Procedia Social and Behavioral Sciences, 114, 933-938. https://doi.org/10.1016/j.sbspro.2013.12.810

Macher, D., Paechter, M., Papousek, I., Ruggeri, K., Freudenthaler, H. H., \& Arendasy, M. (2013). Statistics anxiety, state anxiety during an examination, and academic achievement. British Journal of Educational Psychology, 83(4), 535-549. https://doi.org/10.1111/j.2044-8279.2012.02081.x

Malik, S. (2015). Undergraduates' statistics anxiety: A phenomenological study. Qualitative Report, 20(2), 120-133. https://doi.org/https://doi.org/10.46743/2160-3715/2015.2101

Maryati, I., \& Priatna, N. (2017). Analisis Kesulitan Dalam Materi Statistika Ditinjau Dari Kemampuan Penalaran Dan Komunikasi Statistis. Prisma, 6(2), 173-179.

Nesbit, R., \& Bourne, V. (2018). Statistics Anxiety Rating Scale (STARS) Use in Psychology Students: A Review and Analysis with an Undergraduate Sample. Psychology Teaching Review, 24(2), 101-110. Retrieved from https://journal.uny.ac.id/index.php/jamp/article/view/33058/14278

Olani, A., Hoekstra, R., Harskamp, E., \& Van der Werf, G. (2017). Statistical reasoning ability, self-efficacy, and value beliefs in a reform based university statistics course. Electronic Journal of Research in Education Psychology, 8(22), 49-72. https://doi.org/10.25115/ejrep.v9i23.1427

Onwuegbuzie, A. J., \& Daley, C. E. (1999). Perfectionism and statistics anxiety. Personality and Individual Differences, 26(6), 1089-1102. https://doi.org/10.1016/S0191-8869(98)00214-1

Sandoz, E. K., Butcher, G., \& Protti, T. A. (2017). A preliminary examination of willingness and importance as moderators of the relationship between statistics anxiety and performance. Journal of Contextual Behavioral Science, 6(1), 4752. https://doi.org/10.1016/j.jcbs.2017.02.002

Sandoz, E. K., \& Hebert, E. R. (2017). Using derived relational responding to model statistics learning across participants with varying degrees of statistics anxiety. European Journal of Behavior Analysis, 18(1), 113-131. https://doi.org/10.1080/15021149.2016.1146552

Sariningsih, R., \& Herdiman, I. (2017). Mengembangkan kemampuan penalaran statistik dan berpikir kreatif matematis mahasiswa di kota cimahi melalui pendekatan open-ended (Developing students' statistical reasoning skills and mathematical creative thinking in cimahi city through an open-ended ap. Jurnal Riset Pendidikan Matematika, 4(2), 239. https://doi.org/10.21831/jrpm.v4i2.16685

Septian, A., \& Aulia, S. R. (2021). Kemampuan pemecahan masalah matematis siswa melalui pendekatan problem posing berbantuan edmodo. Prsima, 10(2), $170-181$.

Shiu, E. (2013). Improving learning in statistics - A pilot trial study to achieve the triple effects of depth, breadth and integration. International Journal of Management Education, 11(1), 12-24. https://doi.org/10.1016/j.ijme.2012.11.001 
Siew, C. S. Q., McCartney, M. J., \& Vitevitch, M. S. (2019). Using network science to understand statistics anxiety among college students. Scholarship of Teaching and Learning in Psychology, 5(1), 75-89. https://doi.org/10.1037/st10000133

Steinberger, P. (2020). Assessing the Statistical Anxiety Rating Scale as applied to prospective teachers in an Israeli Teacher-Training College. Studies in Educational Evaluation, 64(March 2019), 100829. https://doi.org/10.1016/j.stueduc.2019.100829

Tutkun, T. (2019). Statistics Anxiety of Graduate Students. International Journal of Progressive Education, 15(5), 32-41. https://doi.org/10.29329/ijpe.2019.212.3

Ulusoy, C. A., \& Altay, M. K. (2017). Analyzing the statistical reasoning levels of pre-elementary school teachers in the context of a model eliciting activity. International Journal of Research in Education and Science (IJRES), 3(1), 2030.

Yusuf, Y. (2017). Konstruksi penalaran statistis pada statistika penelitian (Statistical reasoning construct in research statistics). Scholaria: Jurnal Pendidikan Dan Kebudayaan, 60. https://doi.org/10.24246/j.scholaria.2017.v7.i1.p60-69

Yusuf, Y., Suyitno, H., Sukestiyarno, Y. L., \& Isnarto. (2019). The influence of statistical anxiety on statistic reasoning of pre-service mathematics teachers TT - La influencia de la ansiedad estadística en el razonamiento estadístico de los docentes de matemática con formación inicial. Bolema: Boletim de Educação Matemática, 33(64), 694-706. Retrieved from http://www.scielo.br/scielo.php?script=sci_arttext\&pid=S0103636X2019000200694\&lang=pt\%0Ahttp://www.scielo.br/pdf/bolema/v33n64 /1980-4415-bolema-33-64-0694.pdf

Zhang, J. W., Kessler, E., \& Braasch, J. L. G. (2021). Self-compassion mindsets can predict statistics course performance via intelligence mindsets and statistics anxiety. Learning and Individual Differences, 90(July), 102047. https://doi.org/10.1016/j.lindif.2021.102047 